\title{
A novel trehalosamine isolated from Bacillus amyloliquefaciens and its antibacterial activities
}

\author{
Ying Wang ${ }^{1}$, Bo Zhao ${ }^{1}$, Yaping Liư ${ }^{2}$, Linjing Mao ${ }^{3}$, Xuanming Zhang ${ }^{1}$, Wu Meng ${ }^{4,5}$, Kechun Liu ${ }^{1}$ and Jie Chu ${ }^{1 *}$ (D)
}

\begin{abstract}
Bacillus amyloliquefaciens has been widely used as a probiotic in the field of biological control,and its antibacterial compounds plays an important role in the prevention and control of plant, livestock and poultry diseases. It has the advantages of green, safe and efficiency. This study aims to separate and purify active ingredient from Bacillus amyloliquefaciens GN59 and study its antibacterial activity. A novel compound was isolated from GN59 by column chromatography on silica gel and HPLC purification. The chemical structure was identified as a-D-

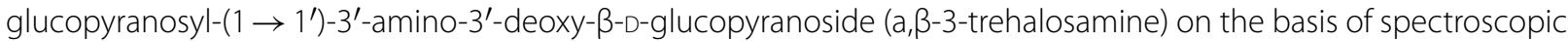
analysis. This is the first report about a, $\beta$-3-trehalosamine isolated from biological resources on an antibiotic activity against pathogenic bacterium. The $3^{\prime}$-neotrehalosamine displayed antibacterial activity across a broad spectrum of microorganisms, including different gram-positive and gram-negative bacteria, with minimal inhibitory concentration (MIC) values ranging from 0.5 to $0.7 \mathrm{mg} / \mathrm{mL}$. The results indicated that the $3^{\prime}$-neotrehalosamine from GN59 might be a potential candidate for bactericide.
\end{abstract}

Keywords: Antibacterial activity, Bacillus amyloliquefaciens, Identification, Environmental friendly

\section{Introduction}

At present, more and more antibiotics have been discovered since Fleming invented penicillin in 1942 that saves countless people infected by microorganism (Mohr 2016; Lambrichts et al. 2017). However, along with the introduction of antibiotics into clinical practice, resistance by pathogenic bacteria has become one of the most important healthy point. More seriously, super-resistant bacteria against all antibiotics have been found such as methicillin-resistant Staphylococcus aureus (Kopp et al. 2004) and NDM-1 bacteria (Kumarasamy et al. 2010). Series of security issues including drug resistance, residual toxicity caused by antibiotics abuse have attracted more and more attention. It has become a valuable research hotspot to find a new and safe substitute with the urgent requirements of environmental protection, green and sustainable development.

\footnotetext{
*Correspondence: chujie6532@163.com

${ }^{1}$ Biology Institute, Qilu University of Technology (Shandong Academy of Sciences), 28789 East Jingshi Road Ji'nan, Shandong 250103, China Full list of author information is available at the end of the article
}

In recent years, much attention has been drawn to natural antimicrobial substances synthesized by some microorganisms as antibiotics alternatives (Pellerito et al. 2018). Bacillus spp. have a wide distribution in the nature, and have been widely used as a probiotic in the field of biological control (Jager et al. 2018; JezewskaFrąckowiak et al. 2018; Lefevre et al. 2017). Its antibacterial compounds play an important role in the prevention and control of plant, livestock and poultry diseases.

Bacillus. amyloliquefacien is a non-pathogenic aerobic gram-positive bacterium. It widely distributes in plant surface, soil, and air. During the metabolic process, it produces a mass of bioactive substances which have antibacterial activity, immunocompetence, antioxidant activity (Xiaolong et al. 2019). It also produces many kinds of enzymes such as alpha-amylase and protease, and shows high adaptability and stress resistance (Du et al. 2018). So it is generally applied in animal husbandry and aquaculture (Cawoy et al. 2014).

A number of Bacillus species play vital roles in controlling diseases due to their secondary antimicrobial
Springer Open (c) The Author(s) 2020. This article is licensed under a Creative Commons Attribution 4.0 International License, which permits use, sharing, adaptation, distribution and reproduction in any medium or format, as long as you give appropriate credit to the original author(s) and the source, provide a link to the Creative Commons licence, and indicate if changes were made. The images or other third party material in this article are included in the article's Creative Commons licence, unless indicated otherwise in a credit line to the material. If material is not included in the article's Creative Commons licence and your intended use is not permitted by statutory regulation or exceeds the permitted use, you will need to obtain permission directly from the copyright holder. To view a copy of this licence, visit http://creativeco mmons.org/licenses/by/4.0/. 
metabolites, such as lipopeptide, macrolide and other active proteins (Chen et al. 2019; Ruan et al. 2019; Wang et al. 2019). Shashidar et al. (2017) have used antagonistic lipopeptides separated from Bacillus UCMB5113 to counteract pathogens. Pengfei et al. (2018) have reported a new antifungal compound, cyclic lipopeptide cyclic lipopeptide was isolated from $B$. amyloliquefaciens HAB2. Abdallah et al. (2018) have indicated that lipopeptides from B. amyloliquefaciens strain 32a could act as promising biocontrol compounds to reduce the plant pathogen Agrobacterium tumefaciens.

In the present study, we isolated a novel bactericidal compound from the fermentation liquid of B. amyloliquefaciens GN59 using column chromatography as isolation and separation technique. Its chemical structure was identified as $\alpha$-D-glucopyranosyl- $\left(1 \rightarrow 1^{\prime}\right)-3^{\prime}$-amino- $3^{\prime}$ deoxy- $\beta$-D-glucopyranoside ( $a, \beta-3$-trehalosamine) on the basis of spectroscopic analysis. This is the first isolated a, $\beta$-3-trehalosamine that has antibacterial activity from biological resources. Further, we characterized the antimicrobial activity properties of a, $\beta$-3-trehalosamine. The minimal inhibitory concentration (MIC) to eight selected strains were between 0.5 and $0.7 \mathrm{mg} / \mathrm{mL}$.

\section{Materials and methods Microorganisms}

Different pathogenic bacterial strains were used to test the antimicrobial activity of metabolites, including Staphylococcus aureus ATCC6538, Micrococcus luteus CMCC280010, Escherichia coli CMCC44102, Salmonella pullorum CVCC533, C79-13, Salmonella gallinarum CVCC79201, C79-1, Salmonella gallinarum CVCC79207, C79-7, Pasteurella multocida CVCC474, C48-7 and Salmonella enteritidis ATCC13076. The strain of B. amyloliquefaciens was got from China General Microbiological Culture Collection Center. It was numbered as CGMCC 1.936, and named GN59 in this paper (http://www.cgmcc.net/index.html). GN59 was cultured in specific fermentation medium ( $30 \mathrm{~g}$ glucose, $7.0 \mathrm{~g} \mathrm{~K}_{2} \mathrm{HPO}_{4} \cdot 3 \mathrm{H}_{2} \mathrm{O}, 3.0 \mathrm{~g} \mathrm{KH}_{2} \mathrm{PO}_{4}, 1.5 \mathrm{~g}\left(\mathrm{NH}_{4}\right)_{2} \mathrm{SO}_{4}$, $0.5 \mathrm{~g}$ trisodium citrate, $0.1 \mathrm{~g} \mathrm{MgSO} \cdot 7 \mathrm{H}_{2} \mathrm{O}$ in $1 \mathrm{~L}$ distilled water, $\mathrm{pH}$ 7.0) and the media was autoclaved at $121{ }^{\circ} \mathrm{C}$ for $20 \mathrm{~min}$. Liquid cultures were shaken at $180 \mathrm{rpm}$ at $37^{\circ} \mathrm{C}$ for $42 \mathrm{~h}$. All other strains were grown on lysogeny broth agar (LB) plates at $28^{\circ} \mathrm{C}$ and cultured at $37^{\circ} \mathrm{C}$ in LB medium.

\section{Chemicals and reagents}

All the chemicals and reagents were analytical grade or highest available purity, and purchased from Sigma Chemical Co.

\section{Antimicrobial activity assay}

The agar-well diffusion method according to the National Committee for Clinical Laboratory Standards (NCCLS) was used to measured the antimicrobial activity of each fraction (Salazar et al. 2017). Different pathogens were cultured in $50 \mathrm{~mL}$ of $\mathrm{LB}$ medium in $250 \mathrm{~mL}$ Erlenmeyer flasks and incubated at $37^{\circ} \mathrm{C}$ with $180 \mathrm{rpm}$ shaking for $12 \mathrm{~h}$. LB agar plates were evenly covered with $1 \times 10^{7} \mathrm{CFU} / \mathrm{mL}$ of suspensions in $100 \mu \mathrm{L}$ and wells of $2.5-\mathrm{mm}$ diameter were formed by a sterile cork borer. $20 \mu \mathrm{L}$ of the separated fractions were added into the wells. Specific solvents were the negative controls and the antibiotic ampicillin $(15 \mathrm{mg} / \mathrm{mL})$ for gram-negative bacteria and vancomycin $(50 \mathrm{mg} / \mathrm{mL})$ for gram-positive bacteria were used as the positive controls. The plates were incubated at $37^{\circ} \mathrm{C}$ for $12 \mathrm{~h}$ and the activities were determined by measuring the diameter of the inhibition zone. The experiments were performed in triplicate.

\section{Extraction, isolation and purification of active compound}

The bacterial precipitate was removed by centrifugation at $8000 \mathrm{~g}$ for $15 \mathrm{~min}$, and the clear supernatant $(2 \mathrm{~L})$ was extracted with methanol $(1: 1, \mathrm{v} / \mathrm{v})$ for three times (each time for $12 \mathrm{~h}$ ) at room temperature to extract the active constituent. The combined solution was concentrated by rotary evaporator at $45{ }^{\circ} \mathrm{C}$. Then the subfractions BA1BA5 were isolated using silica column chromatography with petroleum ether/ethyl acetate (100:0, 75:25, 50:50, 25:75, 0:100, v/v) and the subfractions BA6-BA9 were isolated with ethyl acetate/methanol (75:25, 50:50, 25:75, $0: 100, v / v)$. The active fraction BA8 was further purified by semi-preparative High Performance Liquid Chromatography (semi-HPLC, LC-20A, Shimadzu, Japan) using a YMC-Pack ODS-A column $(250 * 20.0 \mathrm{~mm})$ at a flow rate of $2.0 \mathrm{~mL} / \mathrm{min}$ at $254 \mathrm{~nm}$. Methanol (Sigma, USA) and $\mathrm{H}_{2} \mathrm{O}(7: 3, \mathrm{v} / \mathrm{v})$ were used as the mobile phase in a isocratic elution mode. All peak fractions were collected individually and concentrated via lyophilization to get six components, a (0.8 mg; tR 0.0-1.0 min), b (1.5 mg; tR 1.0-5.1 $\mathrm{min})$ and c (63.1 $\mathrm{mg}$; tR 5.1-5.5 min), d (64.1 mg; tR 5.5-6.5 min), e (1.1 mg; tR 6.5-7 min). Component $\mathrm{c}, \mathrm{d}$ and e were found to contain glycoside components by TLC analyses (data are not shown). Then their antibacterial activity was detected to make sure the active constituent.

\section{The structure analysis of compound with antibacterial activity}

The active compound of fermentation supernatant of GN59 was subjected to NMR and LC-MS analysis to obtain the chromatogram and the prospective mass spectra of the separated compound. NMR spectra was 
recorded $\left({ }^{1} \mathrm{H}\right.$ NMR $400 \mathrm{MHz}$ and ${ }^{13} \mathrm{C}$ NMR $\left.100 \mathrm{MHz}\right)$ on Bruker AMX400MHz Spectrometer (Bruker BioSpin $\mathrm{GmbH}$, Ettlingen, Germany) using deuterated chloroform $\left(\mathrm{CDCl}_{3}\right)$ as solvent. Mass spectrum was carried out using Varian 1200 L Mass Spectrometer (Varian India Pvt. Ltd., Powai, Mumbai).

\section{MIC and MBC of antimicrobial compound}

The minimum inhibitory concentration (MIC) and minimum bactericidal concentration $(\mathrm{MBC})$ of the antimicrobial compound from GN59 against eight tested pathogenic bacterium were determined by micro-broth dilution (Hoelzer et al. 2011). The antimicrobial compound was diluted in 96-well plates by serial dilutions using methanol. Then different bacterium of approximately $10^{5}-10^{6} \mathrm{CFU} / \mathrm{mL}$ was added into each well, mixed gently and then incubated at $37^{\circ} \mathrm{C}$ for $18-24 \mathrm{~h}$. The MICs were recorded by comparing to the growth control and the last concentration. $10 \mu \mathrm{l}$ of each mix liquids diluting with PBS were dropped onto Ashdown's agar for colony counts to evaluate the MBCs. The MBC must have decreased $99.9 \%$ of the bacterial cell count when compared to growth control.

\section{Statistical data analysis}

All experiments were performed as three independent replicates and expressed as mean \pm standard deviation. Data were subjected to analysis of variance using IBM SPSS software (SPSS Inc., Chicago, IL, USA).

\section{Result}

Production time of antibacterial compound

The metabolites from GN59 showed a broadened antimicrobial activity. After being cultured for $12 \mathrm{~h}$, the culture supernatant started to show antibacterial activity against S. aureus ATCC6538 and E. coli CMCC44102. The highest activity was observed at $42 \mathrm{~h}$ with the inhibition zone of 18.3 and $20.9 \mathrm{~mm}$ separately (Fig. 1).

\section{Purification of the antibacterial compound}

The antibacterial effects of the GN59 were evaluated against $E$. coli. $2 \mathrm{~L}$ of specific fermentation medium in a 5 L flask was inoculated at $37^{\circ} \mathrm{C}, 180 \mathrm{rpm}$ for $42 \mathrm{~h}$. An antibacterial compound was purified from the fermentation supernatant of GN59 by bioactivity guided purification. The fraction eluted from eluent (ethyl acetate: methanol 25:75) showed high antibacterial activity. Other fractions didn't have an antibacterial effect (Fig. 2). The active component $(0.5 \mathrm{~g})$ was dissolved in $10.0 \mathrm{~mL}$ of methanol and further purified by HPLC. Fraction A (0.0-1.0 min), fraction $B(1.0-5.1 \mathrm{~min})$, fraction $C(5.1-5.5 \mathrm{~min})$, fraction $\mathrm{D}$ (5.5-6.5 $\mathrm{min})$ and fraction $\mathrm{E}(6.5-7 \mathrm{~min})$ were collected at different period. The results showed that fraction $\mathrm{C}$ had antibacterial activity against $E$. coli (Fig. 3).

\section{Structural analysis of antibacterial compound}

Assignments of ${ }^{1} \mathrm{H}$ NMR, ${ }^{13} \mathrm{C}$ NMR and MS of compound $\mathrm{C}$ are as follows: ${ }^{1} \mathrm{H}$ NMR $\left(\mathrm{CDCl}_{3}, 400 \mathrm{MHz}\right): \delta$ $4.95(\mathrm{~d}, J=2.8 \mathrm{~Hz}, 1 \mathrm{H}), 4.37(\mathrm{~d}, J=7.7 \mathrm{~Hz}, 1 \mathrm{H}), 3.68(\mathrm{~d}$, $J=10.0, \mathrm{~Hz}, 1 \mathrm{H}), 3.66-3.61(\mathrm{~m}, 2 \mathrm{H}), 3.57-3.53(\mathrm{~m}, 4 \mathrm{H})$, $3.40-3.20(\mathrm{~m}, 4 \mathrm{H}), 2.83\left(\mathrm{t}, J^{1 / 4} 8.5 \mathrm{~Hz}, 1 \mathrm{H}\right)$ (Additional

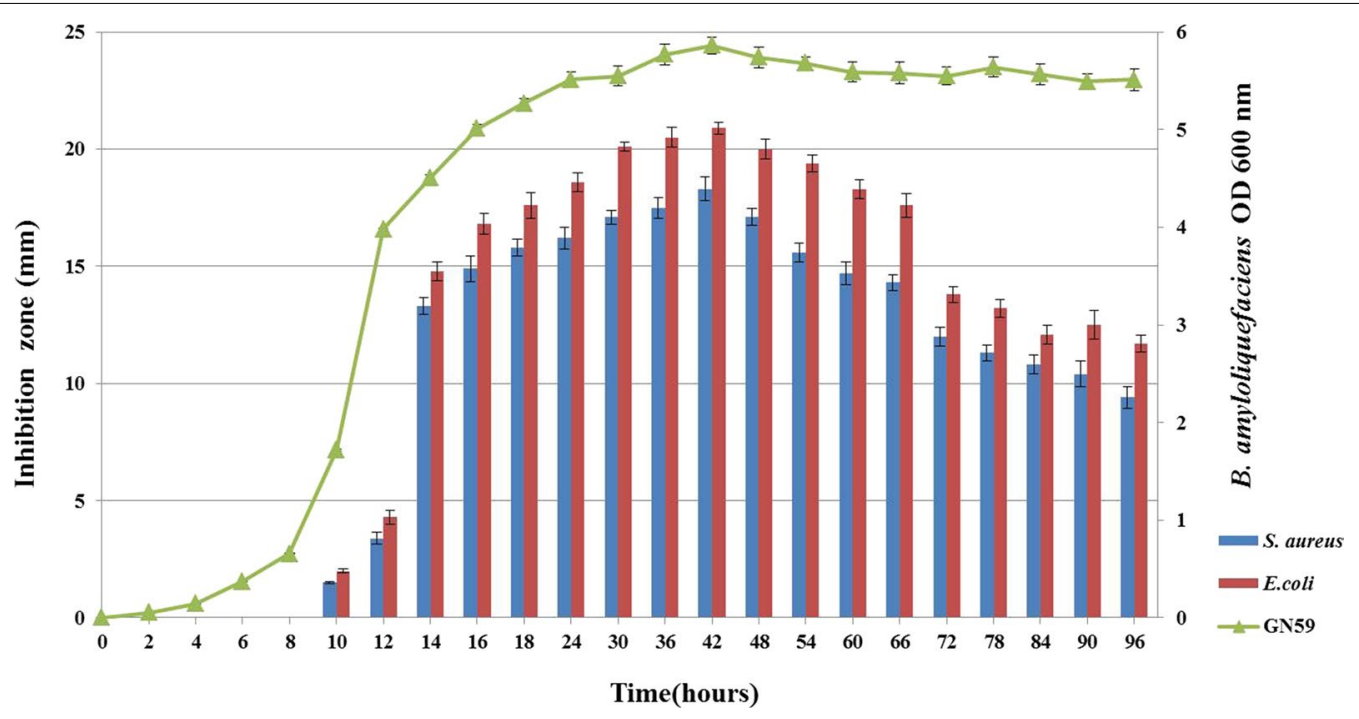

Fig. 1 The production of antibacterial compound from B. amyloliquefaciens GN59. The production of secondary metabolites displayed as sizes of the inhibition zones against S. aureus (blue bars) and E. coli (red bars) by the agar well diffusion method on the left $Y$ axis and growth curve as measured at OD600 $\mathrm{nm}$ of GN59 was plotted on the right $Y$ axis. $X$ axis represented the time in hours 


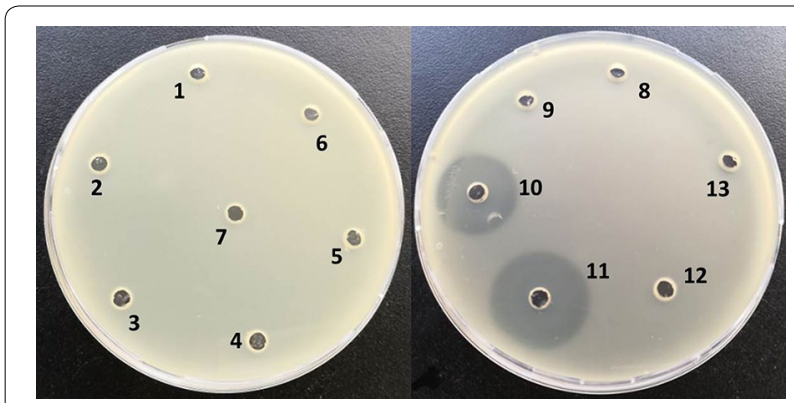

Fig. 2 The antibacterial activity of the elution gradient of silica gel column chromatography. Antimicrobial activity of five fractions of ethyl acetate phase of GN59 fermentation broth the number 1, 2, $3,4,5$ represents different fractions eluted by eluents (petroleum ether:ethyl acetate 100:0; petroleum ether:ethyl acetate 75:25; petroleum ether:ethyl acetate 50:50; petroleum ether:ethyl acetate 25:75; petroleum ether:ethyl acetate 0:100). 6 and 7 represent fractions eluted by ethyl acetate: methanol 75:25. 8 and 9 represent fractions eluted by ethyl acetate: methanol 50:50; 10 and 11 represent fractions eluted by ethyl acetate: methanol 25:75.12 and 13 represent fractions eluted by ethyl acetate: methanol 0:100. The No. 10 and 11 have antibacterial activity agaist E.coli. The experiment was repeated three times

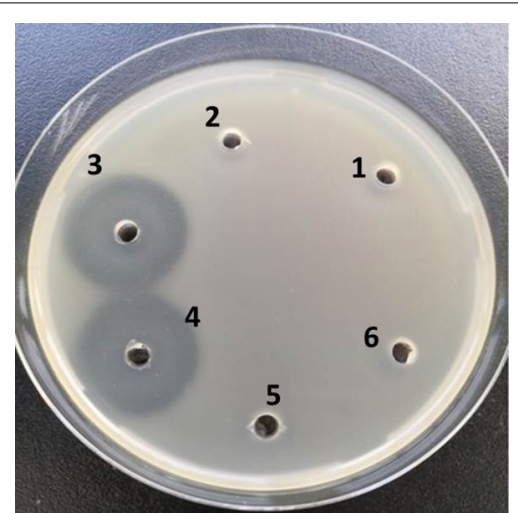

Fig. 3 Antibacterial activity of HPLC collected samples. 1, 2, 3, 4, 5, 6 respectively represent the received samples from period $0.0-1.0 \mathrm{~min}$, 1.0-5.1 $\mathrm{min}, 5.1-5.5 \mathrm{~min}, 5.1-5.5 \mathrm{~min}, 5.5-6.5 \mathrm{~min}, 6.5-7 \mathrm{~min}$. No. 3 and 4 is both from $5.1-5.5$ min which have antibacterial activity against E.coli. The experiment was repeated three times

file 1: Fig. S1); ${ }^{13} \mathrm{C}$ NMR $\left(\mathrm{CDCl}_{3}, 100 \mathrm{MHz}\right): \delta 97.1(\mathrm{C}-1)$, $92.5\left(\mathrm{C}-1^{\prime}\right), 76.9$ (C-5), 76.9 (C-5), $75.1(\mathrm{C}-3), 73.3\left(\mathrm{C}-5^{\prime}\right)$, 72.6 (C-3'), 72.1 (C-4), 0.8 (C-4'), 70.5 (C-2), 61.4 (C-6), $61.1\left(\mathrm{C}-6^{\prime}\right)$ (Additional file 1: Fig. S2); HRMS (positive) $m / z 342.1402[\mathrm{M}+\mathrm{H}]^{+}$(Additional file 1: Fig. S3). The chemical formula of the compound is $\mathrm{C}_{12} \mathrm{H}_{23} \mathrm{NO}_{10}$ after analysis (Fig. 4) which is the same with the substance 34 . (Shazia et al. 2013).

The results revealed that the antibacterial compound of GN59 was proposed to be $\alpha-\mathrm{D}-$ glucopyranosyl- $\left(1 \rightarrow 1^{\prime}\right)-3^{\prime}$-amino- $3^{\prime}$-deoxy- $\beta$-D-

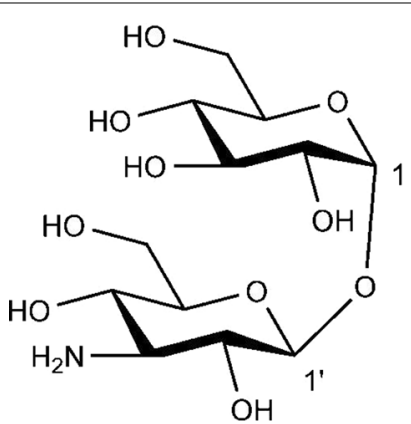

Fig. 4 Structures of $3^{\prime}$-neotrehalosamine. The antibacterial compound was $3^{\prime}$-neotrehalosamine(a-D-glucopyranosyl-( $\left.1 \rightarrow 1^{\prime}\right)$ -3'-mino-3'-deoxy- $\beta$-D-glucopyranoside). Structural formula: $\mathrm{C}_{12} \mathrm{H}_{23} \mathrm{NO}_{10}$

Table 1 Diameters $(\mathrm{mm})$ of the zones of inhibition of growth of all probed bacteria

\begin{tabular}{ll}
\hline Bacteria & $\begin{array}{l}\text { Diameters (mm) } \\
\text { of the zones (0.75 } \mathbf{~ g /} \\
\mathbf{m L})\end{array}$ \\
\hline Staphylococcus aureus (ATCC6538) & $8 \pm 1$ \\
Micrococcus luteus (CMCC280010) & $12 \pm 1$ \\
Escherichia coli (CMCC44102) & $14 \pm 1$ \\
Salmonella pullorum (CVCC533, C79-13) & $15 \pm 1$ \\
Salmonella variant Salmonella gallinarum & $11 \pm 2$ \\
SCVCC79201, C79-1) & $11 \pm 1$ \\
Palmonella gallinarum (CVCC79207, C79-7) & $17 \pm 1$ \\
Salmonella enteritidis (ATCC13076) & $14 \pm 1$ \\
\hline
\end{tabular}

glucopyranoside (a, $\beta$-3-trehalosamine). It is identified as a new trehalosamine, which has the potential to be safe and environmentally friendly bactericide. This is the first report on antibacterial activity of a new trehalosamine from biological resources. The biologically sourced a, $\beta-3$ trehalosamine with antibacterial activity that we discovered represents a new antibacterial compound resource.

\section{Broad-spectrum antimicrobial activities of antibacterial compound}

The new compound a, $\beta$-3-trehalosamine was determined by the well-diffusion to test the broad-spectrum antimicrobial activity and it had a broad-spectrum activity against different gram-positive and gram-negative organisms including $S$. aureus ATCC6538, M. luteus CMCC280010, E. coli CMCC44102, S. pullorum CVCC533, C79-13, S. gallinarum CVCC79201, C79-1, S. gallinarum CVCC79207, C79-7, P. multocida CVCC474, C48-7 and S. enteritidis ATCC13076 (Table 1). The minimum inhibitory concentration (MIC) 
of a, $\beta$-3-trehalosamin was $0.7,0.6,0.5,0.5,0.6,0.6,0.4$ and $0.5 \mathrm{mg} / \mathrm{mL}$, respectively (Fig. 5).

\section{Time-kill assay of antibacterial compound (MBC)}

The results from $\mathrm{MBC}$ assay showed that 3 -neotrehalosamine from GN59 could kill E. coli and S. aureus. E. coli could be killed by $3^{\prime}$-neotrehalosamine at concentrations of $0.5,0.75$ and $1.0 \mathrm{mg} / \mathrm{mL}$ within 24,6 and $3 \mathrm{~h}$ separately (Fig. 6a). S. aureus could be killed by 3 '-neotrehalosamine at concentrations of $0.5,1.0$ and $2.0 \mathrm{mg} /$ $\mathrm{mL}$ within 24, 6 and 3 h separately (Fig. 6b). The killing activity of the active compound was in a dose dependent manner.

\section{Discussion}

Bacillus spp. have been utilized extensively as biopesticides and fungicides in animal feed (Zhao et al. 2017; Mingmongkolchai et al 2017, 2018). B. amyloliquefacien

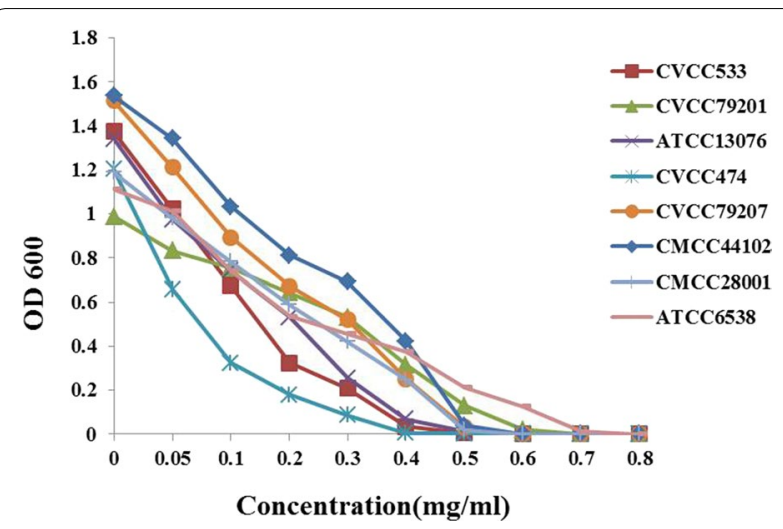

Fig. 5 Broad-spectrum antimicrobial activities was investigated. $X$ axis represented the concentration of $a, \beta$-3-trehalosamine and growth curve as measured at OD600 $\mathrm{nm}$ of GN59 was plotted on the right $Y$ axis is a non-pathogenic aerobic gram-positive bacterium and widely exists in nature. In this study, we report the purification, structure elucidation and antimicrobial activity of $\alpha$-D-glucopyranosyl- $\left(1 \rightarrow 1^{\prime}\right)-3^{\prime}$-amino-3'deoxy- $\beta$-D-glucopyranoside (a, $\beta$-3-trehalosamine)) from B. amyloliquefaciens GN59 fermentation broth. This component displayed strongly antimicrobial activity against most of the pathogenic bacterium. This is the first report on antibacterial activity of a new trehalosamine from biological resources. The biologically sourced trehalosamine with antibacterial activity that we discovered represents a new antibacterial component resource. It showed that the metabolites of probiotics are a potential source for the discovery of new beneficial substances. In addition, the a, $\beta$-3-trehalosamine from GN59 has the potential to be safe and environmentally friendly. Therefore, it may facilitate the potential application in the livestock and poultry farming.

Studies have found that a number of metabolites from microbial strains including lipopeptide, macrolide, surfactin (Santos et al. 2018), fengycin (Fan et al. 2017), iturin (Zhang et al. 2017), bacillomycin D (Tabbene et al. 2016), chitinase (Shehata et al. 2018), and other active proteins ( $\mathrm{Li}$ et al. 2009) have antimicrobial activity. It is reported that the mainly antimicrobial substances produced by Bacillus are presented with different proteins and lipopeptides (Abriouel et al. 2011). The reported non-protein antimicrobial substances mainly include macrocyclic lipids, polyene, phenols (Pinheiro et al. 2018), fatty alcohols (Hayama et al. 2015). However, the antibiotic activity of trehalosamine from bacterium in our study has not been previously reported. a, $\beta$-3-trehalosamine has a broadspectrum antimicrobial activities including different gram-positive and gram-negative bacteria. As far as two gram-positive and five gram-negative strains were
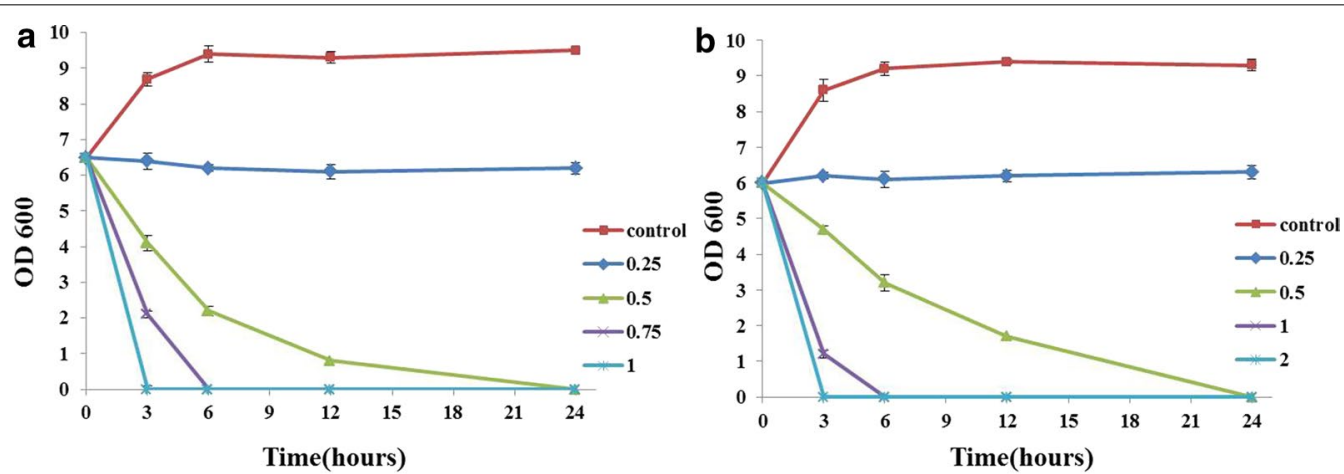

Fig. 6 Time-kill assay of active component from GN59 against E. coli (a) and S. aureus (b). The X axis indicates time in hours after various concentrations of the trehalosamine as indicated $(\mathrm{mg} / \mathrm{mL}$ ) were added into E. coli (a) and S. aureus (b) cultures and the Y axis indicates the CFU/mL of E. coli (a) and S. aureus (b) after treatment 
tested, the antibacterial activity against gram-negative bacteria was stronger than against gram-positive ones. It may be related to the different membrane structure of pathogenic bacteria. We calculate that the antimicrobial effect mechanism of a, $\beta$-3-trehalosamine may destroy membrane structure pathogenic bacteria and cause the death of the pathogenic bacteria. But it needs to be further investigated. The properties of the component suggest a path towards developing biological antibiotic component that are likely to avoid development of multidrug resistance.

During the metabolic process, B. amyloliquefaciens produces a number of bioactive substances which have antibacterial activity, immunocompetence, antioxidant activity. So it is generally applied in animal husbandry and aquaculture. At the same time, it is expected to provide information for further exploration and application. The a, $\beta$-3-trehalosamine we found has strong activity and is easy to synthesize (Shazia et al. 2013). What's more, as a natural antimicrobial substances synthesized by some microorganisms, a, $\beta$-3-trehalosamine show great potential as antibiotics alternatives.

\section{Supplementary information}

Supplementary information accompanies this paper at https://doi. org/10.1186/s13568-019-0943-X.

Additional file 1. Fig S1. Positive HR-ESI-MS data for active substance. Fig S2. $1 \mathrm{H}$ NMR spectrum active subsatnce in $\mathrm{D}_{2 \mathrm{O}}$. Fig S3. ${ }^{13} \mathrm{C}$ NMR spectrum of active substance in $\mathrm{D}_{2 \mathrm{O}}$.

\section{Acknowledgements}

Not applicable.

\section{Authors' contributions}

$J C$ designed the experiments. YW, BZ, YL, LM, XZ and KL performed the experiments. YW prepared figures and/or table, wrote and revised this manuscript. All authors read and approved the final manuscript.

\section{Funding}

This study was funded by the National Key Research and Development Plan of China (Grant Number: 2016YFE0111600), National Science and Technology Cooperation Program of Shandong Academy of Sciences (2019GHPY14), Cooperative Fund for Young Doctors of Qilu University (Shandong Academy of Sciences) (2018BSHZ0030) and Shandong Academy of Science Fund for Distinguished Young Scholars (LKYZ2018-60).

\section{Availability of data and materials}

All data obtained have been included into the manuscript.

\section{Ethics approval and consent to participate}

This article does not contain any studies with human participants or animals performed by any of the authors.

\section{Consent for publication}

The funding agency and all authors consent for publication.

\section{Competing interests}

The authors declare that they have no competing interests.

\section{Author details}

${ }^{1}$ Biology Institute, Qilu University of Technology (Shandong Academy of Sciences), 28789 East Jingshi Road Ji'nan, Shandong 250103, China. ${ }^{2}$ School of Medical Instrument and Food Engineering, University of Shanghai for Science and Technology, Shanghai 200093, China. ${ }^{3}$ College of Animal Science and Technology, Shandong Agricultural University, Tai'an, 271018, Shandong, China. ${ }^{4}$ State Key Laboratory of Biobased Material and Green Papermaking (LBMP), Qilu University of Technology (Shandong Academy of Sciences), Jinan, Shandong 250353, China. ${ }^{5}$ Key Laboratory of Shandong Microbial Engineering, College of Bioengineering, QiLu University of Technology (Shandong Academy of Sciences), Jinan, Shandong 250353, China.

Received: 28 October 2019 Accepted: 28 December 2019

Published online: 14 January 2020

\section{References}

Abdallah DB, Tounsi S, Gharsallah H, Hammami A, Frikha-Gargouri O (2018) Lipopeptides from Bacillus amyloliquefaciens strain 32a as promising biocontrol compounds against the plant pathogen Agrobacterium tumefaciens. Environ Sci Pollut Res Int 25(36):36518-36529

Abriouel H, Franz CMAP, Omar NB, Gálvez A (2011) Diversity and applications of Bacillus bacteriocins. FEMS Microbiol Rev 35(1):201-232

Cawoy H, Mariutto M, Henry G, Fisher C, Vasilyeva N, Thonart P, Dommes J, Ongena M (2014) Plant defense stimulation by natural isolates of bacillus depends on efficient surfactin production. Mol Plant Microbe Interact 27(2):87-100

Chen W, Ma X, Wang X, Chen S, Rogiewicz A, Slominski B, Wan X, Huang F (2019) Establishment of a rapeseed meal fermentation model for iturin $A$ production by Bacillus amyloliquefaciens CX-20. Microb Biotechnol. https ://doi.org/10.1111/1751-7915.13483

Du R, Zhao F, Qiao X, Song Q, Ye G, Wang Y, Wang B, Han Y, Zhou Z (2018) Optimization and partial characterization of ca-independent a-amylase from Bacillus amyloliquefaciens BH1. Prep Biochem Biotechnol 48(8):768-774

Fan H, Ru J, Zhang Y, Wang Q, Li Y (2017) Fengycin produced by Bacillus subtilis 9407 plays a major role in the biocontrol of apple ring rot disease. Microbiol Res 199:89-97

Hayama K, Takahashi M, Yui S, Abe S (2015) Inhibitory effects of several saturated fatty acids and their related fatty alcohols on the growth of Candida albicans. Drug Discov Ther 9(6):386-390

Hoelzer K, Cummings KJ, Warnick LD, Schukken YH, Siler JD, Gröhn YT, Davis MA, Besser TE, Wiedmann M (2011) Agar disk diffusion and automated microbroth dilution produce similar antimicrobial susceptibility testing results for Salmonella serotypes Newport, Typhimurium, and 4,5,12:i-, but differ in economic cost. Foodborne Pathog Dis 8(12):1281-1288

Jager R, Purpura M, Farmer S, Cash HA, Keller D (2018) Probiotic Bacillus coagulans GBI-30, 6086 improves protein absorption and utilization. Probiotics Antimicrob Proteins 10(4):611-615

Jezewska-Frąckowiak J, Seroczyńska K, Banaszczyk J, Jedrzejczak G, ŻyliczStachula A, Skowron PM (2018) The promises and risks of probiotic Bacillus species. Acta Biochim Pol 65(4):509-519

Kopp BJ, Nix DE, Armstrong EP (2004) Clinical and economic analysis of methicillin-susceptible and -resistant Staphylococcus aureus infections. Ann Pharmacother 38:1377-1382

Kumarasamy KK, Toleman MA, Walsh TR, Bagaria J, Butt F, Balakrishnan R, Chaudhary U, Doumith M, Giske CG, Irfan S, Krishnan P, Kumar AV, Maharjan S, Mushtaq S, Noorie T, Paterson DL, Pearson A, Perry C, Pike R, Rao B, Ray U, Sarma JB, Sharma M, Sheridan E, Thirunarayan MA, Turton J, Upadhyay S, Warner M, Welfare W, Livermore DM, Woodford N (2010) Emergence of a new antibiotic resistance mechanism in India, Pakistan, and the UK: a molecular, biological, and epidemiological study. Lancet Infect Dis 10:597-602

Lambrichts S, Van Oudenhove L, Sienaert P (2017) Antibiotics and mania: a systematic review. J Affect Disord 219:149-156

Lefevre M, Racedo SM, Denayrolles M, Ripert G, Desfougères T, Lobach AR, Simon R, Pélerin F, Justen P, Urdaci MC (2017) Safety assessment of Bacillus subtilis CU1 for use as a probiotic in humans. Regul Toxicol Pharmacol 83:54-65 
Li J, Yang Q, Zhao LH, Zhang SM, Wang YX, Zhao XY (2009) Purification and characterization of a novel antifungal protein from Bacillus subtilis strain B29. J Zhejiang Univ Sci B 10:264-272

Mingmongkolchai S, Panbangred W (2017) In vitro evaluation of candidate Bacillus spp. for animal feed. J Gen Appl Microbiol 63(2):147-156

Mingmongkolchai S, Panbangred W (2018) Bacillus probiotics: an alternative to antibiotics for livestock production. J Appl Microbiol 124(6):1334-1346

Mohr KI (2016) History of antibiotics research. Curr Top Microbiol Immunol 398:237-272

Pellerito A, Ameen SM, Micali M (2018) Caruso G Antimicrobial substances for food packaging products: the current situation. J AOAC Int 101(4):942-947

Pengfei J, Wang H, Liu W, Fan Y, Miao W (2018) A new cyclic lipopeptide isolated from Bacillus amyloliquefaciens HAB-2 and safety evaluation. Pestic Biochem Physiol 147:40-45

Pinheiro PF, Menini LAP, Bernardes PC, Saraiva SH, Carneiro JWM, Costa AV, Arruda TR, Lage MR, Gonçalves PM, Bernardes CO, Alvarenga ES, Menini L (2018) Semisynthetic phenol derivatives obtained from natural phenols: antimicrobial activity and molecular properties. J Agric Food Chem 66(1):323-330

Ruan L, Li L, Zou D, Jiang C, Wen Z, Chen S, Deng Y, Wei X (2019) Metabolic engineering of Bacillus amyloliquefaciens for enhanced production of S-adenosylmethionine by coupling of an engineered S-adenosylmethionine pathway and the tricarboxylic acid cycle. Biotechnol Biofuels 12:211

Salazar F, Ortiz A, Sansinenea E (2017) Characterisation of two novel bacteriocin-like substances produced by Bacillus amyloliquefaciens ELI149 with broad-spectrum antimicrobial activity. J Glob Antimicrob Resis 11:177-182

Santos VSV, Silveira E, Pereira BB (2018) Toxicity and applications of surfactin for health and environmental biotechnology. J Toxicol Environ Health B Crit Rev 21(6-8):382-399

Shashidar A, Ongena M, Debois D, De Pauw E, Chen K, Bejai S, Meijer J (2017) Insights into the molecular basis of biocontrol of Brassica pathogens by Bacillus amyloliquefaciens UCMB5113 lipopeptides. Ann Bot 120:551-562
Shazia A, Vetter ND, Rubin JE, Palmer DRJ (2013) Synthesis of 3,3'-neotrehalosadiamine and related 1,1'-aminodisaccharides using disarmed, armed, and superarmed building blocks. Tetrahedron 69:816-825

Shehata AN, Abd El Aty AA, Darwish DA, Abdel Wahab WA, Mostafa FA (2018) Purification, physicochemical and thermodynamic studies of antifungal chitinase with production of bioactive chitosan-oligosaccharide from newly isolated Aspergillus griseoaurantiacus KX010988. Int J Biol Macromol 107(Pt A):990-999

Tabbene O, Azaiez S, Di Grazia A, Karkouch I, Ben Slimene I, Elkahoui S, Alfeddy MN, Casciaro B, Luca V, Limam F, Mangoni ML (2016) Bacillomycin D and its combination with amphotericin B: promising antifungal compounds with powerful antibiofilm activity and wound-healing potency. J Appl Microbiol 120(2):289-300

Wang D, Deng X, Wang B, Zhang N, Zhu C, Jiao Z, Li R, Shen Q (2019) Effects of foliar application of amino acid liquid fertilizers, with or without Bacillus amyloliquefaciens SQR9, on cowpea yield and leaf microbiota. PLoS One 14(9):e0222048

Xiaolong G, Caihuan K, Mo Z, Xian L, Fucun W, Ying L (2019) Effects of the probiotic Bacillus amyloliquefaciens on the growth, immunity, and disease resistance of Haliotis discus hannai. Fish Shellfish Immunol 94:617-627

Zhang Z, Ding ZT, Zhong J, Zhou JY, Shu D, Luo D, Yang J, Tan H (2017) Improvement of iturin A production in Bacillus subtilis ZKO by overexpression of the comA and sigA genes. Lett Appl Microbiol 64(6):452-458

Zhao H, Shao D, Jiang C, Shi J, Li Q, Huang Q, Rajoka MSR, Yang H, Jin M (2017) Biological activity of lipopeptides from Bacillus. Appl Microbiol Biotechnol 101(15):5951-5960

\section{Publisher's Note}

Springer Nature remains neutral with regard to jurisdictional claims in published maps and institutional affiliations.

\section{Submit your manuscript to a SpringerOpen ${ }^{\circ}$ journal and benefit from:}

- Convenient online submission

- Rigorous peer review

- Open access: articles freely available online

- High visibility within the field

- Retaining the copyright to your article

Submit your next manuscript at $\boldsymbol{\nabla}$ springeropen.com 